J. Asiat. Soc. Bangladesh, Sci. 44(1): 15-22, June 2018

\title{
RUSSELL'S VIPER (DABOIA RUSSELII) IN BANGLADESH: ITS BOOM AND THREAT TO HUMAN LIFE
}

\author{
MD. FARID AHSAN ${ }^{1 *}$ AND MD. ABU SAEED ${ }^{2}$ \\ ${ }^{1}$ Department of Zoology, University of Chittagong, Chittagong, Bangladesh \\ 2 555, Kazipara, Mirpur, Dhaka-1216, Bangladesh
}

\begin{abstract}
The occurrence of Russell's viper (Daboia russelii Shaw and Nodder 1797) in Bangladesh is century old information and its rarity was known to the wildlife biologists till 2013 but its recent booming is also causing a major threat to human life in the area. Recently it has been reported from nine districts (Dinajpur, Chapai Nawabganj, Rajshahi, Naogaon, Natore, Pabna, Rajbari, Chuadanga and Patuakhali) and old records revealed 11 districts (Nilphamari, Dinajpur, Rangpur, Chapai Nawabganj, Rajshahi, Bogra, Jessore, Satkhira, Khulna, Bagerhat and Chittagong). Thus altogether 17 out of 64 districts in Bangladesh, of which Chapai Nawabganj and Rajshahi are most affected and 20 people died due to Russell's viper bite during 2013 to 2016. Its past and present distribution in Bangladesh and death toll of its bites have been discussed. Its booming causes have also been predicted and precautions have been recommended. Research on Russell's viper is deemed necessary due to reemergence in deadly manner.
\end{abstract}

Key words: Russell's viper, Daboia russelii, Distribution, Boom, Panic, Death toll

\section{Introduction}

Two species of Russell's viper are known to occur in this universe of which Daboia russelii (Shaw and Nodder 1797) is distributed in Pakistan, India, Nepal, Bhutan, Bangladesh and Sri Lanka (www.reptile.data-base.org); while Daboia siamensis (Smith 1917) occurs in China, Myanmar, Indonesia, Thailand, Taiwan and Cambodia (Wogan 2012). The former one occurs in Bangladesh (Khan 1982, 1992, 2015, Sarker and Sarker 1988, Ahsan 1997, Khan 2008, Islam 2009 and Hasan et al. 2014). Works on Russell's viper in Bangladesh have mostly been done for listing and distribution in the country except Islam (2009) and Hasan et al. (2014) who provided additional information on ecology mainly from literatures. So an attempt was made to collect some information on the species from the field. This paper includes the following aspects of Russell's viper: (1) past and present distribution of the species in Bangladesh, (2) its boom and panic to farmers, (3) bite and death occurrences, (4) awareness of the local people and (5) suggested recommendations.

*Author for correspondence: Email: faridahsan55@yahoo.com 


\section{Materials and Methods}

Published literatures were searched, newspaper reports were collected; physically searched some of the areas of Tanore, Godagari and Nachole Upazilas Rajshahi District and local farmers including some people staffs of Govt. and NGO were interviewed. Furthermore, the distribution of Russell's viper in Bangladesh was also compiled from the survey of the distribution of kraits in Bangladesh through verifying local collections of preserved snake specimens in the museums of 36 different institutes throughout the country (Ahsan and Rahman 2017). The institutes included important public universities, university colleges, colleges, medical college hospitals and museums in the country, which have collections of preserved snake specimens.

\section{Results and Discussion}

Recent records reveal that Russell's viper is found in nine districts but old records say 11 districts and altogether 17 out of 64 districts in Bangladesh (Table 1 and Fig. 1). It is apparent from the distribution (Fig. 1) that the occurrence of the species on record is mainly on lands along the Padma river belts and its connected other rivers and their tributaries (except Patuakhali and Bagherhat cases).

Table 1. Old and recent records of Russell's viper in Bangladesh.

\begin{tabular}{llcc}
\hline Sl. No. & Districts (Upazila) & Old records & Recent records \\
\hline 1. & Nilphamari & Yes & - \\
2. & Dinajpur (Hili) & Yes & Yes \\
3. & Rangpur & Yes & - \\
4. & Bogra & Yes & $?$ \\
5. & Chapai Nawabganj (Sadar, Shibganj, & Yes & Yes \\
6. & Gomatapur, Nachole) & Yes & Yes \\
7. & Rajshahi (Sadar, Poba, Godagari, Tanore) & Yes & - \\
8. & Jessore & Yes & - \\
9. & Satkhira (Assasuni, Kaliganj, Shyamnagar) & Yes & - \\
10. & Khulna (Koira, Paikgacha) & Yes & - \\
11. & Chittagong (Patiya) & Yes & - \\
12. & Naogaon (Dhamoirhat) & - & Yes \\
13. & Natore (Boraigram, Singra) & - & Yes \\
14. & Pabna & - & Yes \\
15. & Rajbari (Pangsha) & - & Yes \\
16. & Chuadanga (Damurhuda) & - & Yes \\
17. & Patuakhali (Kalapara [Kuakata, not upazila]) & - & Yes \\
\hline
\end{tabular}




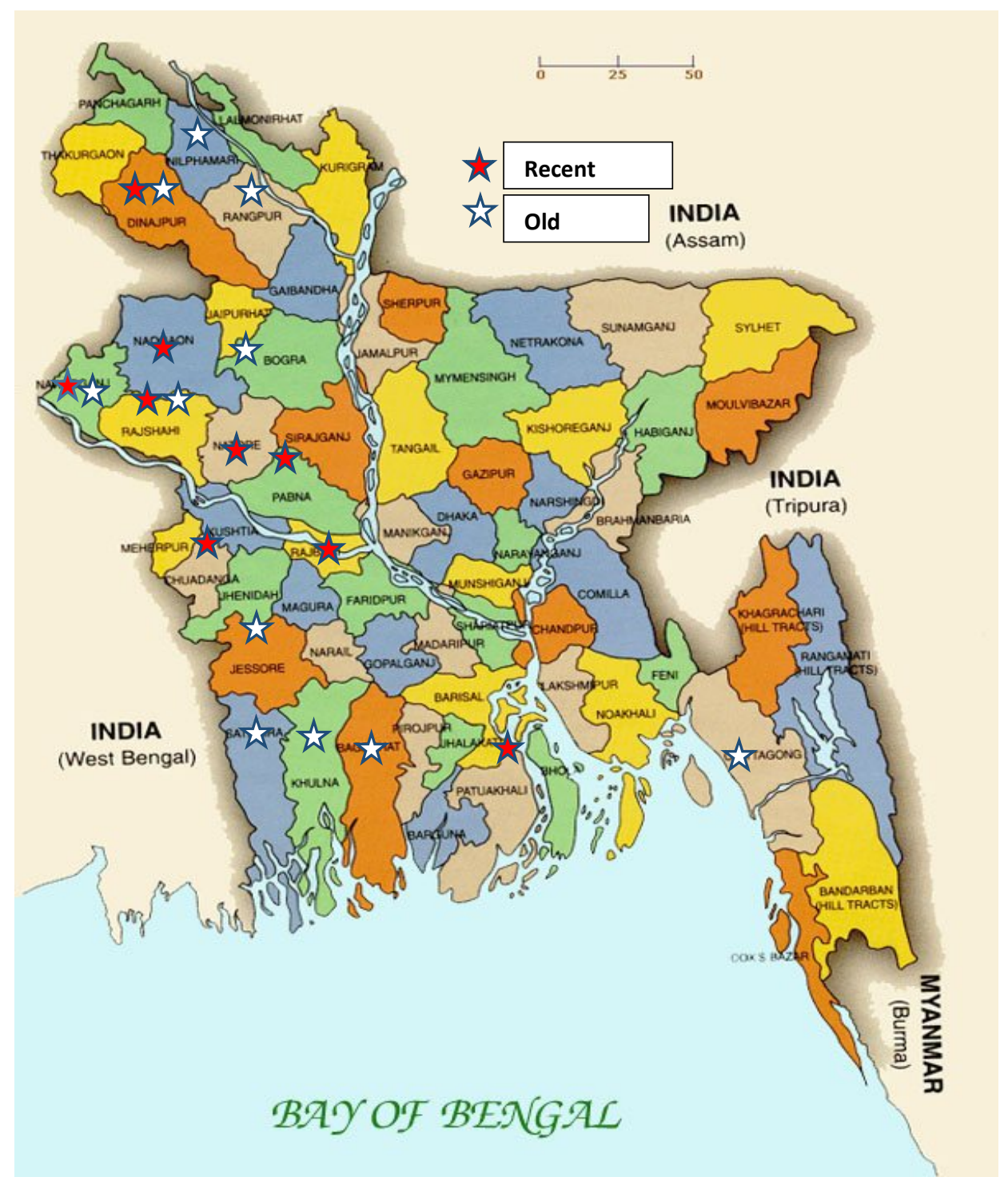

Fig. 1: Distribution of Russell's viper in Bangladesh

Russell's viper is mostly terrestrial but also found in water bodies and it is a good swimmer. It is crepuscular and nocturnal in habit during hot weather but becomes active during day time in the cool weather. It inhibits from plain up to the elevation of 2,100 m asl in south India (Daniel 2002) and found in open, grassy or bushy areas, scrub jungles, forested plantations, rocky hillocks, forest edges, mangroves and farmlands (Whitaker and Captain 2004). It tries to avoid dense forest. Its diets comprise rodents, crabs, frogs, 
lizards and birds (Das 2002). Individuals become sexually mature within 2 to 3 years. Females give birth to 6 - 63 live young during May to November with a peak between June and July with a gestation period of more than 6 months (Daniel 2002, Whitaker and Captain 2004 and Das 2010). The species has recently been assessed as Near Threatened in Bangladesh according IUCN red list assessment categories (Rahman 2015) and it was assessed as Critically Endangered earlier (IUCN Bangladesh 2000).

After one death occurrence of person by Russell's viper bite in Rajshahi Medical College Hospital (RMCH) in 2013, medical doctors especially snakebite researchers came forward for remedies. In fact, one 18 years old school student was bitten in his right forearm by a Russell's viper in Nachole Upazila of Chapai Nawabganj district while he was trying to capture the snake with a misassumption of a non-venomous python. The victim was admitted to RMCH after failure of the traditional healers (i.e., Ozhas) locally. $\mathrm{He}$ died due to wide spread bleeding manifestations, rhabdomyolysis, renal failure and irreversible shock after nine days treatment in the RMCH with 50 vials of polyvalent anitivenom. After that accident there were several incidences of Russell's viper bites in different districts of Bangladesh that drew attention of the physicians and researchers of home and abroad. Medical reports on Russell's viper in Bangladesh reveal that its venom is neuro- myo-nephro- and haemotoxic type (Dr. Robed Amin, pers. comm.).

Table 2. Death case reported of Russell's viper bite in Bangladesh.

\begin{tabular}{|c|c|c|c|c|c|c|c|}
\hline $\begin{array}{l}\text { Sl. } \\
\text { No. }\end{array}$ & Date & District & Upazila & Victim & Sex & Age & $\begin{array}{l}\text { Treatment } \\
\text { received* }\end{array}$ \\
\hline 1. & 13 Mar 2013 & Chapai Nawabganj & Nachole & Anwar Hossain & $\mathrm{M}$ & 18 & $\mathrm{RMCH}$ \\
\hline 2. & 21 Nov 2013 & Rajshahi & Tanore & Taijuddin & M & 25 & $\mathrm{RMCH}$ \\
\hline 3. & 27 Nov 2013 & Patuakhali & Kalapara & Amir Hossain & M & 46 & $\mathrm{DMCH}$ \\
\hline 4. & 04 Apr 2014 & Naogaon & Dhamoirhat & Jamaluddin & M & 35 & $\mathrm{RMCH}$ \\
\hline 5. & 13 Nov 2014 & Rajshahi & Tanore & Azimuddin & M & 26 & $\mathrm{RMCH}$ \\
\hline 6. & 26 Nov 2015 & Rajshahi & Tanore & Yasin Kalu & $\mathrm{M}$ & 50 & UHC \\
\hline 7. & 26 Apr 2016 & Rajshahi & Godagari & Naimul Islam & M & 25 & Ozha \\
\hline 8. & 27 Apr 2016 & Chapai Nawabganj & Gomastapur & Samsu Mia & M & 26 & $\mathrm{RMCH}$ \\
\hline 9. & 29 Apr 2016 & Rajshahi & Godagari & Mousumi & $\mathrm{F}$ & 24 & $\mathrm{RMCH}$ \\
\hline 10. & 01 Jun 2016 & Chapai Nawabganj & Shibganj & Abul Kalam & M & 32 & $\mathrm{RMCH}$ \\
\hline 11. & $05 \mathrm{Jul} 2016$ & Natore & Boraigram & Rashed & M & 30 & Ozha \\
\hline 12. & $12 \mathrm{Jul} 2016$ & Rajshahi & Godagari & Rofiqul Islam & M & 41 & Ozha \\
\hline 13. & 17 Jul 2016 & Rajshahi & Godagari & Ukhi Begum & $\mathrm{F}$ & 38 & Ozha \\
\hline 14. & $20 \mathrm{Jul} 2016$ & Rajshahi & Godagari & Abdul Hakim & M & 36 & Ozha \\
\hline 15. & $22 \mathrm{Jul} 2016$ & Rajshahi & Godagari & Kawser Ali & M & 11 & $\mathrm{RMCH}$ \\
\hline 16. & 05 Aug 2016 & Rajshahi & Godagari & Surjema Begum & $\mathrm{F}$ & 26 & Ozha \\
\hline 17. & 11 Aug 2016 & Rajshahi & Godagari & Mizan & M & 29 & Ozha \\
\hline 18. & 25 Aug 2016 & Rajshahi & Godagari & Shaheb Ali & M & 45 & UHC \\
\hline 19. & 13 Sep 2016 & Rajshahi & Godagari & Helaluddin & M & 28 & $\mathrm{RMCH}$ \\
\hline 20. & 21 Oct 2016 & Rajshahi & Tanore & Abdur Rahim & M & 40 & Ozha \\
\hline
\end{tabular}

Sources: Personal communication, News papers, NGO. * RMCH- Rajshahi Medical College Hospital, DMCH- Dhaka Medical College Hospital, UHC- Upazila Health Complex, OzhaTraditional healers. 
Although it came to limelight in 2013 but in 1995, there was one death record of an indigenous (shawtal) female due to Russell's viper bite in Shibrampur village under Tanore Upazila of Rajshahi district. The victim was treated by a local Ozha (traditional healer) and the local people killed the snake. The actual number of death case has not been maintained accurately by any organization or person but we have compiled it from different sources and found that at least 20 people died due to the bite of Russell's viper in Bangladesh between 2013 and 2016 (Table 2).

Farmers are the main victims of the snake bites because they work in the crop fields and 17 of the dead victims were males, and of which 14 died in 2016, one in 2015, two in 2014 and three in 2013 (Table 2). On the other hand, more than 100 snakes (Russell's vipers) have been killed by local people during that time period. Two of three specimens were rescued from Kulabona char of Poba Upazila under Rajshahi District (kept them in a private snake farm in Poba Upazila), and the other one rescued from the Padma River by fishermen's net in Pangsha Upazila of Rajbari District (kept in a private snake farm in Kalukhali Upazila of Rajbari District). Five individuals were rescued by the Wildlife and Nature Conservation Division, Rajshahi, of the Forest Department and they were released. These rescued and released individuals were: one from Dhamoirhat Upazila of Naogaon District and released on 14 September 2014 at Forhadabad char land afforested area (planted secondary forest) of Godagari Upazila of Rajshahi District; one from Hili Upazila of Dinajpur district and released at Belpukur of Rajshahi on 8 February 2015, two from Godagari Upazila and released at Forhadabad char land afforested area of Godagari and one from Gomastapur Upazila of Chapai Nawabganj District and released it at Belpukur of Rajshahi (M. M. Islam, pers. comm.).

Local people are very much scared of the bite of this species and using local technique like 3 - $4 \mathrm{~m}$ long light bamboo and gentle stir of paddy-plants (so that plants are not damaged) to run off snakes before harvesting crops. A few people are also using gumboots and jeans trouser as a safety measure advised by us. A day-long workshop was arranged with the help of local administration, Upazila Nirbahi (Administrative) Officer (Mr. M. M. Bhuiyan), one medical doctor (Dr. A. S. M. M. Rahman) of RMCH, one Professor (Dr. B. C. Das) of Zoology, University of Rajshahi and NGO member of Baroshik (Mr. Shahidul Islam) in Tanore Upazila of Rajshahi District on 30 November 2015 and one of us (MAS) conducted awareness discussion with local people for getting rid off of snake bite; where and how to do first-aid, prevention and get medical treatment. 
Cause of booming Russell's viper in Bangladesh: It is very difficult to say the actual cause of booming of Russell's viper population in Bangladesh but the following may be the possible reasons:

1. Until 1990s usualy farmers used to cultivate one or two crops in a year and the land remained fallow for rest of the year due to the scarcity of water for cultivating crops;

2. Soon after 1990s farmers are cultivating two to three crops in a year due to the development of irrigation system and little land left fallow. As the crops are available more or less throughout the year and the main food of Russell's viperthe rats, are available in the crop fields, so Russell's viper gets opportunities for reproduction to increase its population;

3. As fallow lands and bushes are very limited so the snakes take shelter in the crop fields;

4. In charland (emerging land area) especially at Forhadpur, an afforestation program of Forest Department has helped to grow good vegetation there and few snakes from India have stranded through flood and got shelter there. Three individuals have been released at Forhadpur char land by the Forest Department. That has helped get mate of the snakes and reproduce in that safe place

5. Converted barren bush land areas (through fires) of Maldah district of West Bengal in India to agricultural land along the borders of Chapai Nawabganj district of Bangladesh may lead to migrate some individuals of Russell's viper to the affected areas in Bangladesh.

Cause of panic of Russell's viper bite: During 2013 to 2016, 20 people died due to the biting of Russell's viper in Rajshahi Division, so the people are panic about the snake and the possible causes of panic of the bites are:

1. People believe that there is no proper medical treatment of Russell's viper bite in Bangladesh;

2. People believe that if a person is bitten by Russell's viper then the death is a time factor;

3. Date of Govt. stocked polyvalent antivenom has expired on 16 August 2016;

4. Doctors and victims are not using the date-expired polyvalent antivenom;

5. Four to five doses are usually needed for treating a Russell's viper victim, which is costly (BDT 40-50 thousands, BDT $80=1$ USD);

6. General mass victim cannot afford the antivenom cost; and 
7. Russell's viper victim also needs dialysis which is costly and general mass people cannot afford it.

\section{Recommendations}

The following recommendations have been suggested for studying Russell's viper:

1. Survey of status and distribution of Russell's viper in Bangladesh be updated;

2. On emergency basis new polyvalent antivenom should be brought through the Govt. initiative;

3. Mono-valent antivenom for Russell's viper is produced in Myanmar and Thailand, so for trial basis it may be brought and be used like done for green pit viper victim in Chittagong Medical College Hospital (collected from Thailand);

4. Snake bite treatment management training program especially for Russell's viper should be initiated for Doctors and Nurses on emergency basis by the Govt. initiative;

5. Public awareness should be created in Russell's viper affected areas including in the schools and colleges;

6. Govt. should take initiative for producing its own antivenom using venom from locally relevant venomous snakes and

7. Incepta Pharmaceutical Ltd. is claiming of manufacturing snake venom antiserum for the first time in Bangladesh but in fact, the company is only marketing antivenom imported from Vins-Bio Products Ltd. of India resulting high cost of antivenom for the poor farmers, who are suffering from snake bites. So Govt. should either take initiative to manufacture the antivenom locally as suggested by WHO in 2009 or import it and supply to the Govt. Hospitals as done earlier for helping the victims.

The known and unknown distribution of Russell's viper (Daboia russelii) in Bangladesh has come in limelight. The probable causes of its boom and panic to farmers have also been pointed out. The awareness programs in the most affected areas have resulted conciseness of the farmers about the snake bite. It has also lessened fear and death toll of people due to snake bites and people have learned to work in the crop fields with cautions. The suggested recommendations may provide further help in policy making and to carry out future work on Russell's viper.

\section{Acknowledgements}

The authors are grateful to the following persons for their help: Mr. M. M. Bhuiyan, Upazila Nirbahi Officer (UNO) of Tanore Upazila, Rajshahi, Dr. A. S.M.M. Rahman of Rajshahi Medical College Hospital, Dr. B.C. Das, Professor, Department of Zoology, University of Rajshahi, Mr. Anam, Pharmacist, Ashoka Laboratories, Rajshahi, Mr. 
Shahidul Islam, Field Officer, Baroshik, Rajshahi, Mr. Shamu, Snake charmer, Tanore, Rajshahi, Mr. Md. Badiuzzaman, Thana Education Officer, Tanore, Rajshahi and three farmers (Md. Golam Mostafa-55, Md. Abu Sayeed-50 and Md. Tofazzal Hossain-50) of Shaivara village under Tanore Upazila of Rajsahhi District.

\section{References}

Ahsan, M.F. 1997. Country report for Bangladesh- Herpetofauna of Bangladesh: Present Status, Distribution and Conservation. In: Biology and Conservation of Amphibians, Reptiles and Their Habitats in South Asia. (Proceedings on International Conference on the Biology and Conservation of the Amphibians and Reptiles of South Asia, Sri Lanka, August 1-5, 1996) (ed A. de Silva). pp. 9-17, Amphibians and Reptiles Research Organization of Sri Lanka, Kandy.

Ahsan, M.F. and M.M. Rahman. 2017. Status, distribution and threats of kraits (Squamata: Elapidae: Bungarus) in Bangladesh. J. Threatened Taxa. 9(3): 9903-9910.

Das, I. 2002. A Photographic Guide to Snakes and Other Reptiles of India. New Holland Publishers (UK) Ltd., London. 144 pp.

Das, I. 2010. A Field Guide to the Reptiles of South-East Asia. New Holland Publishers (UK) Ltd., London. 376 pp.

Daniel, J.C. 2002. The Book of Indian Reptiles and Amphibians. Bombay Natural History Society, Oxford University Press, Delhi. 238 pp.

Hasan, M.K., M.M.H. Khan and M.M. Feeroz. 2014. Amphibians and Reptiles of Bangladesh - A Field Guide. Arannayk Foundation, Dhaka. 191 pp.

Islam, M.A. 2009. Daboia russellii (Shaw and Nodder, 1797). In: Encyclopedia of Flora and Fauna of Bangladesh, Vol. 25. Amphibians and Reptiles (eds. S.M.H. Kabir, M. Ahmad, A.T.A. Ahmed, A.K.A., Rahman, Z.U. Ahmed, Z.N.T. Begum, M.A. Hassan, and M. Khondker). Asiatic Society of Bangladesh, Dhaka. pp. 172-173.

IUCN Bangladesh. 2000. Red Book of Threatened Amphibians and Reptiles of Bangladesh. IUCNThe World Conservation Union, Bangladesh. 95 pp.

Khan, M.A.R. 1982. Wildlife of Bangladesh: A Checklist. The University of Dhaka, Dhaka. 174 pp.

Khan, M.A.R. 1992. Bangladesher Shap (Snakes of Bangladesh) (in Bengali), Bangla Academy, Dhaka. 227 pp.

Khan, M.A.R. 2015. Wildlife of Bangladesh: Checklist and Guide. M. J. Alam, Chayabithi, Dhaka. $568 \mathrm{pp}$.

Khan, M.M.H. 2008. Protected Areas of Bangladesh: A Guide to Wildlife. Nishorgo Program, Bangladesh Forest Department, Dhaka. 304 pp.

Rahman, M.M. 2015. Daboia russelii. In: IUCN Bangladesh. Red List of Bangladesh Volume 4: Reptiles and Amphibians. IUCN, International Union for Conservation of Nature, Bangladesh Country Office, Dhaka. p.103.

Sarker, M.S.U. and N.J. Sarker. 1988. Wildlife of Bangladesh (A Systematic List with Status, Distribution and Habitat). The Rico Printers, Dhaka. 69 pp.

Whitaker, R. and A. Captain. 2004. Snakes of India - The Field Guide. Draco Books, Chennai. 479 pp.

Wogan, G. 2012. Daboia siamensis. The IUCN Red List of Threatened Species 2012: e.T201501A2707729. http://dx.doi.org/10.2305/IUCN.UK.2012-1.RLTS. T201501A2707729. en.Downloaded on 06 December 2016.

www.reptile-database.reptarium.cz/species?genus=Daboia\&species=russelii. Downloaded on 06 December 2016. 